\title{
Short and Long-Run Effects of Public Investment: Theoretical Premises and Empirical Evidence
}

\author{
Pasquale Lucio Scandizzo $^{1}$, Maria Rita Pierleoni2 ${ }^{*}$ \\ ${ }^{1}$ Faculty of Economics, University of Rome "Tor Vergata”, Rome, Italy \\ ${ }^{2}$ Department of Economic Planning, Presidency of Council of Ministers, Rome, Italy \\ Email: scandizzo@uniroma2.it, `m.pierleoni3@virgilio.it,mr.pierleoni@governo.it
}

How to cite this paper: Scandizzo, P. L., \& Pierleoni, M. R. (2020). Short and Long-Run Effects of Public Investment: Theoretical Premises and Empirical Evidence. Theoretical Economics Letters, 10, 834-867. https://doi.org/10.4236/tel.2020.104050

Received: July 7, 2020

Accepted: August 9, 2020

Published: August 12, 2020

Copyright ( 2020 by author(s) and Scientific Research Publishing Inc. This work is licensed under the Creative Commons Attribution International License (CC BY 4.0).

http://creativecommons.org/licenses/by/4.0/ (c) (i) Open Access

\begin{abstract}
This survey focuses on the impact of public investment as an instrument of economic policy. The study presents and analyzes features and results of the empirical works on this theme taking into account both theory and estimations issues. In general, the studies surveyed support the idea that public investment, if projects are properly selected, raises output and welfare through both demand and supply effects and thus should be the instrument of choice of economic policy for governments and public agencies. Moreover, a considerable amount of empirical studies show that public investments have higher positive growth effects than public consumption both in the short and in the long run. In spite of a great diversity in the theoretical approaches and the empirical results, the studies surveyed tend to converge in many indications that can be useful to policy makers. Among these, in addition to several pointers on the reasons why public investments may be made more effective, is that a major challenge is to provide a new generation of global public goods for sustainable development.
\end{abstract}

\section{Keywords}

Public Investment, Multiplier, Models Employed, Persistence of the Multiplier

\section{Introduction}

As the world emerged from the global financial crisis, the recovery in many advanced economies remained tepid and there were worries that a slow down or even a recession might be imminent, in spite of the seemingly robust, but perhaps unsustainable growth in the US economy. Then, the sudden appearance of 
the coronavirus epidemics changed everything and precipitated the global community in what looks as a new and yet unexplored abyss of uncertainty. To date we still don't know to what extent and how this medical black swan, arriving only shortly after the financial one, will change the economic landscape. One certainty, among many unknowns, however, is that it has exposed a wide unpreparedness of national governments and international institutions in responding to the emergency with an adequate supply of public goods such as health facilities and services and effective global coordination. An additional certainty is that, after the emergency will be over, a massive program of public intervention will be needed to reconstruct a world economy shuttered by an unprecedented combination of symmetric demand and supply shocks.

Before the ongoing crisis, modern societies seemed already to be haunted by the ghost of missing growth. The inability to generate persistent growth had been also described as a scenario of "secular stagnation" (Summers, 2013; Teulings \& Baldwin, 2014), which might have been worsened by tight fiscal policy and consolidation measures focused on expenditure cuts on public investment. Fiscal constraints were particularly strong in the Euro area because of the strict rules of the Stability and Growth Pact (SGP) and the additional policy reactions after the onset of the euro crisis. In this context some studies show that the fiscal consolidation should allow some support to growth through public investment (Spilimbergo et al., 2009; Romer, 2012; Hakhu et al., 2014). Perhaps following this suggestion, one solution that had figured prominently in the early program of the Trump administration and by other institutions-e.g. European Commission-was a boost in public infrastructure investment.

In addition to these suggestions, which stem from explicit as well as implicit considerations on the demand and the supply side, many recent international initiatives appear to support the idea that the supply of global public goods is increasingly inadequate and that some form of multinational or transnational public capital is needed to respond to global challenges, such as, in particular climate change and the pervasive systemic risks of an increasingly hyper-connected world (Chichilnisky, 2012).

In general terms the recent empirical literature supports the idea that public investment raises output through both demand and supply effects (Aschauer, 1989; Straub, 2008; Romp \& de Haan 2005; de Haan et al., 2008; Chakraborty \& Dabla-Norris, 2009; IMF, 2014, 2015). The study by Aschauer (1989) is generally considered to be the starting point of this line of research. This author was the first to hypothesize that the decrease in productive government services in the US may be crucial in explaining the general decline in productivity growth in that country. Based on his results, a $1 \%$ increase in the public capital stock was estimated to raise total factor productivity by $0.4 \%$. On the waves of these empirical findings, other studies have followed with considerable consensus forming on the proposition (Sturm et al., 1998; de Haan et al., 2008) that public capital by means of public investments generally furthers economic growth. 
From the point of view of the policy makers, these findings are a clear indication that public investment is generally a valid policy tool, and that it acts both on boosting demand and increasing productive capacity. An important, related question, however, concerns how to prioritize and select the different forms of public capital to be provided and then which investment programs to implement. This implies knowing how public capital affects economic systems, since there is some consensus on the fact that public capital represents the "wheels" - not the engine-of economic activity (World Bank, 1994) and infrastructure investment is not sufficient on its own to generate sustained increases in economic growth. This question has received only scant attention in the literature, but it appears crucial to direct public capital spending toward more precise objectives of economic growth. Technological progress and the increasing importance of global public goods also make other related questions especially important for policy makers. These include further aspects of how public capital can affect economic growth in the new context of global value chains and hyper-connected economic agents around the world. Among these, the following features of public capital appear especially relevant: 1) the network character of infrastructure services which implies network externalities; 2) economies of scale related to infrastructure in terms of lower fixed costs, attracting companies and factors of production and, thereby, raising production (Haughwout, 2002; Egger \& Falkinger 2003); 3) public infrastructure and especially new "smart" facilities as important instruments of competitive location policy because of high spillover effects depending on the size of the country or region concerned and its openness $^{1}$; 4) according to the so called new economic geography (e.g., Krugman, 1991; Holtz-Eakin \& Lovely, 1996; Venables, 1996; Fujita et al., 1999)—which considers transport costs a central determinant of the location and scale of economic activity and of the pattern of trade-infrastructure and in particular transport infrastructure has a profound impact on the size of the market, because it enables producers to cluster and exploit joint economies of scale; v) the relation with private capital i.e. the extent to which private and public capital are substitutes or complements. Most of these effects are quantitatively unknown, but they may be empirically measurable if monitoring the efficiency of public capital through cost benefit and impact analysis becomes itself part of public investment policies (de Haan et al., 2008). The heart of the problem is the intrinsic difficulty of identifying truly exogenous and unanticipated changes in public investment in the macroeconomic data and also in tracking their dynamic effects over time. New techniques of impact evaluation, however, offer policy makers and development practitioners the means to meet the challenge (Gertler et al., 2016).

The research objective of this survey concerns the study of the impact of pub-

${ }^{1}$ One simple way to model these spillovers has been suggested by Cohen and Morrison Paul (2003) which considered in a cost function of the manufacturing sectors in thhe US states not only the public capital stock in the state concerned, but also the public capital stock in geographically connected states. 
lic investment as an instrument of economic policy, taking into account its short and long run effects on various aspects of the economy. We devote a particular attention to the definition and the estimate of public investment multiplier, which has come under special scrutiny in the recent past as an especially contentious parameter to evaluate government performance and guide policy choices. To this aim we present first a review of the theoretical principles and the main models developed in the literature to evaluate the investment impact. We also analyze key features and results of the main empirical works on this theme, taking into account both theory and estimations issues. Finally, we elaborate on the practical implications that can be useful to policy makers.

\section{The Theoretical Base for the "Multiplier"}

The concept of multiplier owes its popularity to the treatment of John Maynard Keynes (1936), even though its origin can be traced as far back in time as the $17^{\text {th }}$ century with the physiocrats and the famous Quesnay's "tableau economique" (1972). While the etymology conveys the general idea of an effect that is a multiple of an original impulse, the meaning of multiplier in economics is more complex and is based on a mechanism of diffusion throughout the economic system brought about by a chain of direct and indirect outcomes, that can have different origin, qualities and size, depending on a sequence of cause-effect relationships. Almost invariably, however, a "multiplier" is generated by linkages that extend across value chains and function as vehicles to propagate and possibly to magnify an exogenous shock to an interdependent economic system. For example, the original Keynesian multiplier derives from the idea that an exogenous increase in expenditure results in a direct increase in the incomes of a group of recipients and this turns into further expenditure, which turns itself into income and so on and so forth until the original impulse has exhausted its (multiplying) power.

On the other hand, the development economics literature has long cultivated the idea that the extent and the strength of multiplier effects in an economy depend on its connectedness, i.e. the existence of backward and forward linkages across its different economic agents (Leontief, 1936; Hirschman, 1958) and of concomitant factors such as complementarities and superstar effects (Jones, 2008). In neoclassical growth theory, for instance, a capital multiplier arises because more capital leads to more output, which in turns leads to more capital, according to a virtuous cycle which can be represented mathematically as a geometric series summing to a multiplier of $1 /(1-k)$, where " $k$ " is the capital share of total output. Since $\mathrm{k}$ is of the order of $1 / 3$, the capital multiplier appears unduly low and correspondingly the rate of return to capital unduly high, which has moved many scholars and the international organizations to try to incorporate into the estimates of national accounts additional forms of productive assets such as human and natural capital (Jones, 2008; Perali \& Scandizzo, 2018). Nevertheless, the multiplier obtained from the capital output ratio in the neoclassical 
growth model exemplifies a process of accumulation, diffusion and growth which is itself dependent on the linkages existing across the different sectors of the economy.

Similarly to the capital multiplier, the notion of the intermediate goods multiplier (Leontief, 1936; Stone, 1960) depends on the capacity of the different value chains of the economy to receive and propagate an exogenous expenditure impulse to the whole economy. As in the case of the capital multiplier, intermediates increase in response to production increase and in turn cause additional increases in output throughout the economy according to a sequence of decreasing effects that can also be represented as a geometric series and converge to a value of $1 / 1-a$, where " $a$ " is the share of intermediate goods in total output. Since this share for an advanced economy is of the order of 50\%, the resulting multiplier is of the order of 2, a large enough effect that is at the base of the modern analysis with the input-output models and the so called social accounting matrices or SAM (Perali \& Scandizzo, 2018).

In the discussion on macroeconomic policies, much of the debate still centers on the so called fiscal multiplier, that is on the different forms taken, through the various theories and empirical applications, of the multiplier proposed by Keynes in his "General Theory". Originally, this multiplier derived from the simple definition of income as the sum of endogenous and exogenous expenditure, the endogenous component being related to income through the consumption function. As in the case of the capital and the intermediate goods multiplier, the mechanism identifies a phenomenon whereby an exogenous increase in expenditure (typically by the government, hence the name of "fiscal multiplier") gives rise to a geometric series of subsequent increases that converge to a value of $1 / 1-c$, where " $c$ " is the marginal share of income claimed by consumption. The "instantaneous" multiplier effect of this share, which is thought to be of the order of $80-90 \%$, may be tempered by several concurring factors: 1 ) the fact that in practice it occurs over time, 3 ) the marginal propensity to consume may vary under the influence of variables such as income level and distribution, prices, and interest rates, 3) factor supply cannot be freely expanded, 4) money supply may not be accommodating, 5) disposable income depends on taxation, and 6) the process of increasing consumption is dampened by import spending. Allowing for these conditions may considerably reduce the multiplier. For example, if taxes and imports are considered, the multiplier will converge to a value of $1 /(1-(c-m)(1-t))$, where " $m$ " is the marginal propensity to import and " $t$ " the marginal tax rate. For $c=0.9, m=0.2$ and $t=0.5$, this formula gives a value of about 1.5, which is an order of magnitude often encountered in the attempts of empirical measurement.

The basic equation for the so called Keynesian fiscal multiplier is the definition of GDP:

$$
Y=C+G+X-M
$$

where $Y=\mathrm{GDP}, C=$ private consumption, $G=$ government expenditure, $X=$ 
export, $M=$ import.

Differentiating both sides of (1), assuming that exports do not change, we obtain:

$$
d Y=c(1-t) d Y+d G-m(1-t) d Y
$$

Solving for the multiplier gives:

$$
\frac{d Y}{d G}=\frac{1}{1-(c-m)(1-t)}
$$

The three sets of multipliers (i.e. the consumption, the intermediate goods and the capital multipliers) described, however, are mutually compatible and could very well work together. Considering the effect of intermediate goods, in particular, it can be shown that this effect acts multiplicatively on the expansion of demand and output, so that the resulting multiplier, is $1 /(1-a)(1-(c-m)(1-t))$, and the order of magnitude of the fiscal multiplier for $a=0.5$ becomes 3 . Adding the capital multiplier is less straightforward since this is a second order effect (the so called "accelerator"), which acts by further increasing investment of the product between the multiplier and the capital share, i.e. assuming the low figure of $30 \%$ for the latter, an accelerator of an order of magnitude of $90 \%$ or, for an exogenous shock of 1 Euro of investment a secondary increase of 90 cents.

The effects of investment increases are different from those of current expenditure because they include two distinct impacts on the economy. The first impact occurs in the so-called "construction period", and unfolds on demand because of an impulse to capital spending and the consequent creation of work income and the purchase of goods and services. The effect is anti-cyclical, in the sense that acts by increasing income toward its potential, full employment value, from which it may have temporarily diverged because of non-persistent negative shocks. The expansion of consumption directly and indirectly linked to the investment determines what is usually called "multiplier", but in the case of investment it is important to notice that the expansionary effect is primarily the consequence of an increase in capital spending, which affects the composition of the government budget and may have long lasting consequences on government capabilities and endogenous expenditure.

These consequences are important for policy makers and include the fact that capital spending does not tend to generate claims from expecting recipients, thus leaving the government freer from the burden of political obligations from involuntary entitlements. While the first impact raises the level of income with respect to the level that the economy can attain for a given production capacity, the second effect is on the productive capacity and thus on the growth potential of the economy. It occurs as the capital expenditure turns into effective capital formation, e.g. productive machinery and, because of the role of government, in an increase in the production capacity of the infrastructures or of other public goods put into operation. This effect (if the investment was properly selected by cost benefit analysis) is always greater than the government-backed expenditure 
for its implementation. A third, complementary impact that may accompany the expansion of public capital, is the so-called "crowding in", which arises from the fact that private entrepreneurs, in the presence of more efficient infrastructures, in turn expand their investments by determining further positive effects on the economy.

The above effects can be greatly magnified by scale economies and more than proportional rewards of the "superstar" variety, especially when the multipliers act to determine the distribution of resources across competing actors, as for instance on the distribution of traffic (a special type of transactions) in a communication network or of incomes or assets across economic agents. In these cases, the multiplier mechanism, together with complementarities and superstar effects, appears to be a plausible cause of the cumulative nature of phenomena such as the great concentration of wealth across countries, with differences between rich and poor countries in incomes per capita up to 50 times, and extreme forms of the Pareto power law.

Current measurements of all these effects are still far from accurate and derive from a series of assumptions on the parameters' constancy and the lack of feedback between their values and the expenditure increases, which have been abundantly challenged in the past years by important mainstream economists, such as Friedman, Modigliani, Lucas. These criticisms, which for a long period of time have succeeded in challenging the theoretical basis, if not the empirical evidence, of Keynesian models, were all based on the idea that the operators' reaction to an expenditure shock could not be considered independent of the shock itself and the expectations associated with it.

More recently, however, multipliers have become popular again, because of a combination of two circumstances: a new generation of micro-founded economic models and in a related, but independent fashion, a large amount of empirical studies showing significant evidence of multiplying effects of public expenditure. A special issue much debated by policy advisers has also been the extent to which the multiplier can act to increase growth and reduce debt as a share of GDP. As demonstrated by DeLong and Summers (2012), in what can be characterized as a prototype of a family of "new Keynesian" models, in the short term a debt-financed increase in public investment as a share of potential GDP leads to a change in the debt-to-potential GDP ratio, while in the longer run, these effects are countered by the emergence of supply effects from the increase in productive capacity, and productivity that efficient investments will generate. While DeLong and Summers (2012) focus on the idea that a deep recession will cast a shadow on future growth in the form of negative hysteresis, their reasoning has more general validity and can be exemplified by a few orders of magnitude. For example, consider a demand-constrained economy with a fiscal multiplier of 1.5 and a real annual interest rate on long-term government debt of $1 \%$. In this economy a $\$ 1$ increase in GDP increases the net tax-and-transfer fiscal balance by $\$ 0.33$, while a $\$ 1$ shortfall of GDP below po- 
tential this year is assumed to permanently reduce future potential GDP by \$0.01 (the hysteresis "shadow" on future potential output). Assuming no risk penalties on the cost of debt (no "spread" increases), the effect of a temporary increase of $\$ 1$ of government spending is to increase current GDP and debt respectively of $\$ 1.5$ and $\$ 0.50$, with additional yearly real debt service of $\$ 0.005$. Because of the countering of the hysteresis shadow (which would have been $-1 \%$ ), the $\$ 1.50$ increase in this year's GDP has an impact on expected future potential output of $\$ 0.015$, and on future-period tax revenues of $\$ 0.005$. This last effect offsets the increase in the debt service and makes the fiscal expansion self-financing.

In determining actual responses to policy stimuli, one component of the theoretical literature focuses on the obstacles that multipliers may find in generating positive effects on the economy. These obstacles may first reside in the low connectivity of the economic system with relatively few linkages, or with linkages blocked by bottlenecks of various nature, such as resource constraints, institutional inadequacies, bureaucratic inefficiencies and knowledge and technology gaps. They can also be the consequence of the so called crowding out effects, that is the fact that increases in government expenditure, or any other exogenous impulse that could result in a multiplier effect, may be substituting or reducing endogenous expenditure that would have occurred in a counterfactual situation. The simplest case of this effect occurs in the neoclassical model of the interest rate determination, where this is brought about by the equilibrium between savings and investment, both being a function of the rate of interest. In this case, assuming for simplicity a closed economy, the crowding out effect arises directly from the market equilibrium condition:

$$
S=I \Rightarrow S_{0}-G_{c}+\sigma r=G_{k}-\lambda r
$$

where $S_{0}$ is an autonomous component of the savings function, $G_{c}$ and $G_{k}$ are respectively government current and capital expenditure and $r$ is the rate of interest. Solving (1) for the equilibrium rate of interest $r^{\star}$, we obtain:

$$
r^{*}=\frac{1}{\lambda+\sigma}\left[\left(G_{c}+G_{k}\right)+S_{0}\right]
$$

Substituting into (1) and differentiating w.r.t. the two types of government spending, we obtain:

$$
\frac{\mathrm{d} I}{\mathrm{~d} G_{c}}=-\frac{\lambda}{\lambda+\sigma}
$$

and

$$
\frac{\mathrm{d} I}{\mathrm{~d} G_{k}}=\frac{\sigma}{\lambda+\sigma}
$$

These expressions indicate two different crowding out effects: current government expenditure reduces total investment, while capital spending increases it, though by a multiplier which is necessarily less than unity and approaches 
unity as investment interest elasticity goes to zero.

In computable general equilibrium (CGE) models ${ }^{2}$, market competition for resources reduces the multiplier by increasing the costs of expanding supply in response to the demand increases, with a mechanism that may include, according to the different "closures" that can be chosen, the savings-investment equilibrium mechanism of the neoclassical model. All CGE formulations, in fact, even in their forms that are closer to the Keynesian paradigm, exhibit an aggregate supply function that reflects resource limitations and thus dampens the multiplier effects in any comparative static simulations. In dynamic CGE models, however, the multiplier is generally boosted by capital increases and aggregate supply and demand functions are both shifted outward by the increase in productive capacity and efficiency brought about by larger stocks of public capital (Perali \& Scandizzo, 2018).

From the point of view of policy makers, the theoretical objections to the multipliers can serve as caveats on the design of public investment policies, where no quick fixes nor spectacular successes should be expected under ordinary circumstances and many constraints may tend to reduce the scope and the size of public projects. At the same time, most models show that high multiplying effects of public investment can be generated if government capabilities and efficiency are adequate, economic circumstances are especially dire or both.

The logical connection between theory and practice in the use of investment multiplier is also important to account for its somewhat elusive features, including its high variability across studies, and its use by political advocates to argue for or against government intervention. Much of the ambiguities and the misunderstandings associated with it, however, relate to the fact that its very notion, size and economic interpretation depend strictly, and vary widely with the theoretical underpinnings, the economic models and the estimates used to generate it. In this respect, the term "model" is intrinsically ambiguous since it refers both to the explicit theoretical structure underlying the economy under analysis and the implicit inference mechanism used for estimation and measurement. This semantic difficulty can be recognized in the dichotomy between the models mostly employed to measure the multipliers and other effects of fiscal and monetary policies, which are based either on the simulation side, with the economic structure playing the main analytical role, or of the vector auto-regression (VAR) variety, focusing on the inference side. Because the models of both types adopt a linear dynamic approach, as argued by Parker (2011), they tend to ignore the state of the economy and implicitly assume that there is a country and time-invariant fiscal multiplier. Thus, a more recent strand of models extends the analysis to non-linear dynamics and to state-dependent fiscal multipliers, with the objective to explain some of the anomalies of the great recession and provide estimates for the output response in different regimes

${ }^{2}$ For further details on the use of general equilibrium models in applied research see Kehoe \& Prescott. 1995. 
(Warmedinger et al., 2015). Most of differences may appear highly technical, but they can be useful also for policy makers, to identify the source and the logic of the results obtained and the policy prescriptions derived. Even in the case of high level economic institutions like the IMF or the World Bank, in fact, that policy indications come from one model rather than another often appears to be of no consequence unless other characteristics can be called into play, such as ideologies, common sense principles, or personal trust in different schools of thought or specific persons. Identifying what is due to the theoretical hypotheses and some of the technicalities of the model can thus help to separate the effects of rigorous assumptions from prejudice.

According to Gechert (2015), we can distinguish three classes of macro models at the basis of the modern theory of multipliers: 1) the new classical Real Business Cycle (RBC) dynamic stochastic general equilibrium (DSGE) models, 2) the New Keynesian (NK) DSGE models and, 3) the structural macro-econometric models (MACRO). RBC models originated from Kydland and Prescott (1982) idea that cycles are not started by monetary surprises, but by total factor productivity (TFP) shocks ${ }^{3}$. These models embrace the concept of optimal growth based on utility-maximizing representative households for whom Ricardian equivalence holds with fully competitive labor and goods markets. Because neo-Ricardian agents are insensitive to intertemporal distribution of government taxes and expenditures, not only public expenditure crowds out private investment, but its capacity to increase incomes through multiplying effects is severely limited. As a consequence, RBCs model expansionary fiscal policies in a way that is constitutionally unable to increase GDP except through wealth and substitution effects that force increased labor supply (Baxter \& King, 1993). Because government expenditure subtracts resources to the private sector, the balance between the positive effect on labor supply and the negative effect of crowding out results in a range for output multipliers of $0<k<1$, with the precise value depending on the elasticities of demand for labor and the elasticity of substitution of consumption and leisure (Woodford, 2011). These results may be somewhat modified by complementarity effects introduced via different assumptions on households' utility functions, which may rise the multipliers above 1 (Linnemann, 2006; Mazraani, 2010), or by crowding out and tax distortionary effects which may even generate negative multipliers (Ardagna, 2001; Fatàs \& Mihov, 2001). In both cases, it may be argued that multiplier is a misnomer for the effects on aggregate output of increased government expenditure, since there is no effect generated by a chain of expenditures following the original shock, but only a general equilibrium adjustment to a new balance between public and private expenditure.

New Keynesian (NK) models retain the basic RBC framework on fiscal multipliers, but expand its structure according with some of the tenets of Keynesian

${ }^{3}$ By adding persistent TFP shocks to a stochastic version of the Brock and Mirman (1972) optimal growth model, Kydland and Prescott were able to reproduce the dispersion of US time series (Azariadis, 2018). 
macroeconomics, by introducing monopolistic competition and sticky prices or wages, as well as a rule for money supply. The result, in addition to a somewhat greater realism of the market mechanism, is a mathematical structure that can be summarized in three equations: 1) an IS curve, 2) a Phillips curve, both arising from first order conditions for the aggregate households and the monopolistic firm, and 3) a Taylor rule. NK models thus result in a framework, which resembles the IS-LM famous construct of the so called neo-classical synthesis (Azariadis, 2018: p. 1546), where fiscal expansion may be needed because of difficulties and lags in adjustments to unexpected shocks. While crowding out and Ricardian expectations still tend to dominate the scene, resulting "multiplier" effects are able to move within a broader spectrum in both the upward and the downward direction.

In both $\mathrm{RBC}$ and $\mathrm{NK}$ models, multipliers may be $<0$ when including distortionary taxation, a wage-level increasing effect of public employment, or risk premia on interest rates for high government debt. On the other hand, multipliers may climb above 1 if a share of Keynesian consumers is introduced, with expenditures aligned with incomes (Galì et al., 2007; Cwik \& Wieland, 2011; Eggertsson \& Krugman, 2012), and/or an expansive monetary policy that operates at the zero lower bound (ZLB) of the interest rate (Freedman et al., 2010; Woodford, 2011).

Because these models adopt neoclassical assumptions of optimizing behavior in determining labor supply and demand, respectively by the representative household and the representative firm, not only an increase in government spending does not act as a stimulus to private consumption, but necessarily crowds out part of it. As a consequence, a micro-foundation based on this type of model closure is constrained, by its very nature, to yield multipliers that are lower than 1 , even in the presence of market imperfections such as monopolistic power or price distortions of various form. Outside the context of the neoclassical framework, on the other hand, a "new Keynesian benchmark" is provided by a dynamic version of the demand led macro-models, where the optimizing micro-foundations of representative agents' behavior coexist with "sticky" prices and wages, and the monetary policy is assumed to be able to credibly maintain the interest rate fixed at all times, regardless of the chosen path of government purchases. Under these assumptions, as in the "benchmark" case illustrated by Woodford (2011), the predicted multiplier may be equal or greater than one, but only in the special circumstances determined by a combination of recession and extremely accommodating monetary policies. In this case, the multiplier is also independent on the degree of resource slackness, i.e. it is independent of the cost of supply, even though such a cost does matter in determining the cost of the monetary policy measures needed to maintain the interest rate constant (cost of present goods in terms of future goods or indexed bonds).

In sum, "New Keynesian" DSGE models are able to deliver multipliers, which have different genesis and structure than their original "old Keynesian" coun- 
terparts. Their orders of magnitude resemble old Keynesian levels, only under the limiting conditions of extremely accommodative monetary policies and zero lower bounds interest rates. In this case they may be considerably larger than one, since government expenditure will push the price level upward, thus reducing real interest rates to negative values with "crowding in" effects on real balances. These models thus generate multipliers consistent with the hypothesis that the expansionary effect of a fiscal stimulus is contingent on the existence of a liquidity trap that brings to the limit the countercyclical capacity of monetary policy and thus justifies proactive inflationary spending. They are unable to yield Keynesian multiplier effects in a post-crisis environment where monetary policy is not expected to accommodate an increase in aggregate demand (Hausman, 2016). Moreover, the dominance of monetary expansion over fiscal policy of the "New Keynesians" reverses the original idea of money supply changes to aid or contrast a fiscal stimulus. According to their logic, in fact, monetary policy that is able to maintain price stability at all times is the most effective means of increasing aggregate demand. At the same time, it is also the optimal policy from the point of view of resource allocation, since it acts through the market in a neutral way, and thus corresponds to a first best (full information) allocation, as described by neoclassical theory. Government expenditure, on the contrary, being necessarily nonneutral in the sense that it consists of a specific pattern of purchases, is likely to determine a suboptimal allocation of resources, thus reducing the efficiency of the economy.

The policy scenarios where DSGE models display multiplier effects comparable to those of the earlier Keynesian models may seem extreme, but they have been made more relevant by the recent global economic crises, including the current one, where monetary authorities have continued to be the first and the fastest implementers of stimulus packages and are de facto operating at the zero lower bound of interest rates. Under these conditions, central bankers and policy makers appear to hold the justified belief that, in spite of the vast differences in the theoretical approaches and the seeming heterogeneity of the empirical findings, public expenditure multipliers can be confidently predicted to be large.

Because of their state-of-the-art characteristics, DSGE models have acquired great currency with national governments and international institutions. In addition to highly simplified model structures and somewhat unrealistic assumptions on agents' rational behavior, they have also other weaknesses. As noted in IMF (2012), fiscal policy assumptions remain controversial and, unlike the Taylor rule for monetary policy, no generally accepted fiscal rule is available to be used in a DSGE. The models are often calibrated, or estimated by using Bayesian methods, so that their results depend on the choice of prior distributions and key parameters (e.g., degree of price and wage rigidities, habit persistence, investment adjustment cost, and proportion of liquidity-constrained agents). They rely heavily on the assumption of representative agents, linear approximations and expert choices by modelers (Perali \& Scandizzo, 2018). According to some 
institutional users (IMF, 2012; OECD, 2014), they tend to give more uniform responses for different countries than econometric studies and their forecasting performance tends also to be similar across different studies and analytical frameworks. As noted by Azariadis (2018), technically, DSGE models are also characterized by stationary equilibria with small, real and positive dominant eigenvalues that are at odds with results from VARs and often fail to reproduce the hump patterns observed and predicted by VAR models in reaction to economic shocks.

The models that appear more faithful to the Keynesian paradigm are the so called structural macro-econometric models. These models estimate backward-looking macroeconomic consumption and investment functions and do not incorporate utility-maximizing agents. Most of them combine Keynesian reactions in the short run with neoclassical features in the long run. They typically lead to multipliers larger than 1, exclude or play down crowding out effects, while often including crowding-in effects on private consumption or investment, depending on the monetary and foreign trade regime. Examples of this class are: 1) the Fall \& Fournier (FF) model; 2) the Fiscal Maquette (FM) model and 3) the NiGEM macroeconomic model (Al-Eyd \& Barrell, 2005; Mourougane et al., 2016).

A more empirical strand of the literature applies VAR econometric methods and various SEE (single equation estimations) techniques, generally producing a wider range of results than DSGE model estimates and simulations. Since there are obvious endogeneity problems when it comes to estimating fiscal multipliers, the literature has developed several identification schemes (Gechert, 2015). For VAR studies, out of the five established approaches of identification of exogenous fiscal shocks, two rely on additional historical information, and three try to identify exogenous fiscal shocks directly from the time series (Caldara \& Kamps, $2008)^{4}$. In the last decades, the VAR identification process and structural characteristics of fiscal systems defined by Blanchard and Perotti (2002), based on a priori economic restrictions ("Structural” VAR or SVAR) became a benchmark for the econometric approach to multiplier estimation. The current research focuses on applying the VAR methodology to the stage of the business cycle (regime-switching models) because there are strong theoretical and empirical arguments in support of the thesis that multipliers are higher in times of crisis (Auerbach \& Gorodnichenko, 2012b, 2013) and they have been often underestimated leading to large growth forecast errors (Blanchard \& Liegh, 2013).

\section{Time to Build, Persistence and Permanence}

An additional characteristic of the study design is the method to estimate the multiplier. In this respect, policy makers should appreciate the differences between static and dynamic multipliers (respectively SM and DM) and the many policy implications of these differences in planning investment and expecting

${ }^{4}$ For further insights: Ramey and Shapiro, 1998; Romer and Romer, 2010; Fatàs and Mihov, 2001; Blanchard and Perotti, 2002; Mountford and Uhlig, 2009. 
and measuring results. SMs arise from comparative static experiments, refer to steady state effects (i.e. from one to another equilibrium without adjustment paths) and may take time to materialize. DMs result from dynamic simulations both of the steady states and the transition paths. These differences in turn are related to the characteristics of duration of the multipliers, such as time to build, persistence and permanence. These features are especially important for policy planning since the real outcomes generated by the multipliers depend on their predictable effects per unit of time, as well as their timing in terms of beginning, continuing and ending impacts. Investment multipliers are different from general expenditure multipliers because they indicate responses to exogenous shocks that are necessarily displayed over time and often over long periods of time. More precisely, investment shocks can be considered temporary, even though extended over a number of years (for example the construction of a single infrastructure lasting a certain number of years and not to be necessarily followed or replicated in the near future), or permanent (an investment program lasting over the entire planning horizon of the government, and increasing public investment expenditure as a percentage of GDP over the same foreseeable future). Because SMs only compare steady state outcomes (with and without the investment), their results have to be interpreted within a time horizon necessary to reach the long term equilibrium or the steady state. DMs, on the other hand can be calculated for each year and along a specific path simulated with the model.

As for persistence, this feature may be useful to discriminate between "big bang" policy interventions that have a short term large, but soon vanishing effects from gradual changes whose effects build up gradually and last longer. Persistence may refer to the duration of the shock or of its effects, although in practice the two may be difficult to disentangle in an SM. Since investment duration can be measured separately for the construction (time to build) and the operational period (the economic life of the project), SMs can be used to capture persistence due to the perception of the construction activities and their expected duration, while DMs are the tools of choice to estimate effect persistence as a consequence of their speed and progress. Although the empirical evidence on the subject is scant, two forces may be at work in determining effect persistence: on one hand, in line with all types of fiscal stimuli, the mechanism of anticipated change tends to gradually reduce the impact on demand, and to cause it to vanish within 5 years, even for permanent fiscal shocks (IMF, 2014). The unpredictability of large investments timing and expenditure may also work in the opposite direction, by conjuring up continuous surprises and unanticipated shocks, that may fuel a form of persistence of an entirely different nature. In the operational period, which for public investment tends to be of long duration (20+ years for general infrastructure), shock persistence may be less important as compared to long term effects on productivity, which may prolong both the perception of permanence of government measures and their effective persis- 
tence over time. The long term hysteresis described by DeLong and Summers (2012), in particular, can be considered a special case of this form of persistence, especially difficult to detect when it is the consequence of small yearly losses of productive capital as a consequence of a transitory, but deep recession.

The persistence of the multiplier is also tightly linked with its so called "hydraulic" properties 5 , e.g. the leakages or the "leaks out" and "leaks in" in the chain of incomes and expenditure, which are ultimately related to the cyclical nature of the income streams in a market economy, and their dependence on positive or negative feedback loops. In this respect, the multiplier can be considered part of a conservation law characteristic of the circulation of income through a chain of transactions, which may be originated by injections, may be eroded by small, but persistent losses ("leaks out") due to different interactions with the environment (e.g. savings, imports, and crowding out) or reinforced by further injections and "leaks in" (essentially induced injections through the "crowding in" of private investment). In determining the multiplier behavior over time a major role is also played by the lag between the stimulus and the response and by whether the stimulus is permanent (or is perceived as such) and the response persistent.

These phenomena are also related to the propagation process of the multiplier, whose time-life depends on the original impulse as much as on its casual encounters along the road during the period in which its effects are constructed and displayed. In the original Keynesian conception, the multiplier was an essentially comparative static construct, originated by the theory that while savings are endogenous to income determination, investment is the autonomous consequence of entrepreneurial decisions inspired by the market sentiments (the "animal spirits"). Any increase in investment was thus matched by an equal increase in savings as the result of income rising to support its new level to achieve equilibrium. The process of adjustment was thus ignored, and essentially left unexplored and unknown. In a dynamic setting, however, two distinct questions emerged. First, what was the level of the multiplier in the presence of a permanent, as opposed to a temporary, increase in the investment level. Second, what was the amount of investment consistent with a permanent increase in supply to match the aggregate demand increase fueled by the multiplier. These two questions are closely related to government policy planning and especially to the relationship between the budget short term measures and its longer term allocations, including the relationship between financing and project preparation.

The increase in aggregate demand spurred by the investment in the construction period does not necessarily match the increase in productive capacity and other supply side effects such as total factor productivity increases and crowding in phenomena. In order to achieve a durable increase in the overall economic

${ }^{5}$ Hydraulic mechanisms concern the streams of incomes and expenditures generated by the original expenditure shock and the leakages and lags in the system that allow the sequence of effects to converge to a definite multiplier. 
growth, the aggregate demand generated by a permanent increase in investment spending during construction should be matched by an equal permanent increase in aggregate supply in the investment operational phase. As a consequence, especially non marginal investments are likely to cause disequilibria and subsequent price and wage adjustments that may themselves contribute to the size, the direction and the duration of any multiplier effect. If resources are highly underutilized because the economy is in recession or stagnation, on the other hand, the effects on aggregate demand are likely to prevail on those on supply, because they will be immediate and larger, thus helping the economy to reach a new and more favorable steady state more quickly. Insisting on public investment spending while the economy is slowing down is thus intuitively the right anti-cyclical policy, even in the presence of risky and/or lower return projects, because investment is the only type of public spending that is likely to increase both demand and supply along a path converging to a steady state. On the other hand, in periods of economic booms, supply effects are more important than aggregate demand ones, and project selection standards should be tightened to make sure that adjustment to new equilibria occurs without adverse inflationary consequences.

Spilimbergo et al. (2009) and Gechert (2015) describe several different techniques of calculation of the multiplier over time used in the literature. Most empirical models, especially VARs, provide impulse response functions (IRFs) of standardized fiscal policy shocks. An IRF can be defined as a mathematical representation of a variable of interest over time after a shock in a given moment. It is thus implicitly referred to a multiplying process occurring over time, through a process of transition and possibly of convergence to a steady state. In VAR studies IRFs are hump shaped, with a slow build up and decaying periods, characteristics that DSGE models generally fail to reproduce (Azariadis, 2018). Multipliers are calculated either as the peak response of GDP with respect to the initial fiscal impulse (FI), or as the cumulative response function of GDP divided by the cumulative fiscal impulse function, or, as a third alternative, as the average impact response divided by the average impact impulse. In the case of comparative static experiments, where public expenditure is raised as a single shock, models typically yield a single multiplier, which corresponds to the cumulative response over an unspecified transition path to the steady state represented by the new equilibrium reached by the model. For a shock lasting more than one period, however, as for example the case of an investment built over a discrete amount of time, even comparative static exercises yield more than one multiplier, with possible cumulating effects over time as project construction ends and the effects of expanding capacity start emerging. In dynamic simulations, these effects over time are more organically linked to one another, since not only a new steady state but also a transition path are computed. Both comparative static and dynamic simulations thus present some time structure for the multipliers, but they can be compared only by taking into account that the static exercises 
essentially neglect all adjustment lags along the path from the old to the new equilibria.

\section{Time Structure and Identification}

According to Gechert (2017), a large set of channels influence the fiscal policy impact estimates and their time structure characteristics. These include i) the "hydraulic" mechanisms of the system under study, ii) the kind of the fiscal instrument itself, iii) the institutional settings on markets, and iv) agents' expectations and behavior. Because of mutually exclusive assumptions and different model settings, no unique standard of comparison exists, which makes Carroll (2009) argue that "Asking what 'the' government spending multiplier is, [...] is like asking what 'the' temperature is. Both vary over time and space. The really interesting intellectual questions involve the extent to which the whole set of other important factors causes the multiplier to vary".

Duration and time structure of the multiplier combines with the crucial weakness of almost all estimates of the impact of a fiscal stimulus, which is the missing of the counterfactual. Control groups in macroeconomics in fact are hard to find, so that identification is mostly attempted by focusing on a single entity and historical variance. When a pattern can repeatedly be observed over time with some variance, then the average of this pattern is taken as a rule and the rest remains unexplained variance. This is usually done in macro-econometric time series analysis where fiscal multipliers are estimated according to a stylized framework such as:

$$
\Delta G D P_{t+i}=\hat{a}+\hat{k} \sum_{j} \Delta F I_{t+j}+\hat{\varepsilon}_{t+i}
$$

with $\triangle G D P_{t+i}$ being the change in GDP growth and $F I_{t+j}$ the GDP percentage change in an expenditure or taxation component of the budget. In the case of an expenditure shock, this can consist of current and/or capital expenditure and gives rise to four main estimation problems:

I) identification, since causation may be both direct, running from $\Delta F I_{t+j}$ to $\Delta G D P_{t+i}$ and reverse (Blanchard \& Perotti, 2002). In this respect, the literature has developed various identification schemes based on: a) instrument variable (IV); b) narrative record; c) war episodes; d) cyclical adjustment; e) recursive VAR approach; f) VAR with prior restrictions from economic theory (structural VAR or SVAR); g) sign-restrictions VAR approach. The different approaches lead to different estimates and the reported multiplier appears to systematically depend on the method chosen with no consensus having been reached on a benchmark method (Gechert, 2015). The fact that the Blanchard \& Perotti (2002) SVAR approach and the narrative record sometimes serve as terms of comparison may reflect their popularity rather than their superiority (Gechert, 2017):

II) omitted variable biases, when the error term contains influences on GDP 
(e.g. changes in the price level or the exchange rate). The way to deal with this problem is to control with additional variables but this strategy has to take into account the cost of reducing the degrees of freedom and the need to keep models parsimonious;

III) unrecognized anticipation effects, when the change in fiscal policy is anticipated by the private sector (Ramey \& Shapiro, 1998);

IV) nonlinearities, which may render the averaging results of linear approaches misleading. For example, an estimation of average multipliers would be an inadequate forecast of the effects of a stimulus in a recession because in this period some factors that promote high multipliers prevail. Nonlinearities are usually treated by distinguishing regimes. The recession vs. upswing or the crisis vs. non-crisis are the most important regimes utilized, but also exchange rate and public debt regimes have been tested (Corsetti et al., 2012).

In sum, given their specific characteristics, VARs and structural macro-econometric models should be considered a viable alternative and, for many aspects, a complement to micro-founded simulation (DSGE) models. Policy makers should be aware that, in spite of their more empirical orientation and easier theoretical structures, these models have both strengths and weaknesses leading to a large set of possible biases and uncertain results ${ }^{6}$. For example, VAR models and other econometric techniques can only partially control the issue of reverse causation and all have their specific merits and problems (Gechert, 2017), but seem to control effectively the anticipation effects. The structural macro-econometric models, in spite of allowing short run Keynesian reactions and long run neoclassical features, cannot be said to be micro-founded and typically imply several restrictions on the data. VAR models may be better suited (and are easier to estimate) than structural models to capture non-linear behavior, especially when the economy diverges severely from its steady state. However, this comes at the cost of possibly omitting important structural relationships characterizing the economy (Warmedinger et al., 2015).

\section{Literature on Empirical Results: Short and Long Run Effects}

A key policy question concerns the different performance of public investment expenditure in the short and in the long run. Short term effects may concern the immediate effectiveness of investment spending in a deep recession or, as in the present circumstances due to the coronavirus emergency, the prospect of a depression where a stimulus is urgently needed to reassure the financial markets on the capacity and the willingness of the government to fend off a catastrophic fall in aggregate demand. Compared to current expenditure, in principle public investment appears to be slow moving and subject to a more vexing series of administrative, legislative, regulatory and implementation lags. These have been

${ }^{6}$ Zanna et al. (2019) argue for a more critical vision about the robustness of VAR models and related results. 
actually increasing in recent times because of concern with competition, corruption-that reduces the confidence in public institutions (Clausen et al.., 2011) - and special interests, as well as the need to improve the quality and efficiency of public projects (Warner, 2014). The short term effects of public investment are limited to their announcement effects and their impact during the "construction period", where investment expenditure acts on demand through capital spending and the consequent creation of work income and the purchase of goods and services. Even though still subject to larger administrative and implementation lags, during this period investment expenditure is more readily comparable with current government expenditure and, as shown in Warner (2014) appears to be more clearly associated with a positive impact on the economy than in the long run, where reverse causation phenomena are more difficult to detect. The reason for this that an increase in public infrastructure boosts aggregate demand through the short-term fiscal multiplier (because the expansion of consumption directly and indirectly linked to the investment), similar to other government spending. In addition to these effects, the literature presents some evidence that, due to their particular characteristics, capital expenditures, and especially those for infrastructure are more effective since they exhibit a pattern that is completely different from other types of government spending (Leduc \& Wilson, 2013; de Haan et al., 2008; Romp \& de Haan, 2005).

In general terms, we should expect public investment to be characterized by a high degree of variability about the size of the short term multipliers. The reasons are several and include the fact that capital expenditure is not the same as actual increase in productive capacity or infrastructure. Thus, while the multiplier in the construction period of an investment project depends on the nature of the capital goods that are purchased to implement the investment (the "producing" sectors mobilized by the investment), once the project is completed, what counts is the increase in productive capacity of the infrastructure affected, (the "proprietary" sector). In both cases, however, investment works on the demand and the supply side, during the construction period because it mobilizes key capital producing sectors and, once the project is completed, in the operational period, through its impact on productivity and efficiency of both public and private investment. However, these effects may vary widely across countries and time and may "crowd out" or "crowd in" private investment. For example, while results are controversial, several empirical studies suggest that investment multipliers are larger during recessions and smaller in the presence of weak public finances, particularly when debt sustainability is at risk. In addition, multipliers depend on how the expenditure is financed, whether through debt, increases in revenues or cuts in other expenditure categories (ECB, 2016). In DSGEs, not surprisingly, investment multipliers are larger if crowding out of private investment is limited or assumed away by extreme liquidity conditions, where in fact "crowding in" would prevail.

In this section we present the results of the most important empirical works 
on this theme. The presentation aims to identify the most significant studies and to illustrate the degree of variability on the size of the short and long term multipliers emerging from the empirical analysis.

An example of earlier empirical work on the effects of public investment spending is the study by Chandra and Thompson (2000), who compared the local earnings before and after the completion of a new highway at the local county. They found that earnings are higher during the periods of highway construction ( 1 - 5 years before completion) compared to when the highway is completed and that earnings after completion grows over many years. Binswanger, Khandker, and Rosenzweig (1993) and De Frutos and Pereira (1993), on the other hand, found that in the short run the growth of output is relatively unresponsive to changes in the public capital stock, even though they underlined that this result does not imply that public capital has no (long-run permanent) effect on output.

Other empirical literature on the short run effects of capital expenditure has often focused on military spending (Ramey \& Shapiro 1998; Edelberg, Eichenbaum, \& Fisher, 1999; Fisher \& Peters, 2010; Ramey, 2011; Barro \& Redlick, 2011; Nakamura \& Steinsson, 2014, among others). Changes in defense spending due to military conflicts-even though they may be subject to implementation lags and anticipation effects-are more likely to be exogenous to movements in economic activity than changes in public infrastructure spending. For non-military spending, however, a study by Auerbach and Gorodnichenko (2012a) presents estimates of consumption and investment multipliers in the US, using a Smooth Transition Vector Autoregression that allows the multipliers to differ in recessions and expansions. They find high multipliers and investment multipliers much higher than the consumption ones, particularly in recessions (the cumulative investment multiplier in recessions is 3.42 , while the corresponding consumption multiplier is 1.47).

Leduc and Wilson (2013) examine the dynamic macroeconomic effects of infrastructure investment on highways in United States. Following Auerbach and Gorodnichenko (2012a), they extend the analysis to investigate whether highway spending shocks occurring during recessions lead to different impulse responses than in expansions. They find-using a VAR technique-that the initial impact occurs only for shocks in recessions, while later effects are not statistically different between recessions and expansions. Their baseline results show that highway spending shocks positively affect GDP at two specific horizons, i.e. there is a significant impact in the first couple of years and then a larger second round effect after six to eight years. The multipliers range between 1 and 3 on impact and between 3 and 7 at six to eight years out. Other estimates of local fiscal multipliers tend to be between 1 and 2. They also found that highway spending - at least the kind of highway spending typically done over the past twenty years-may not be well suited to be an effective type of stimulus spending. On the contrary, the highway funding shocks occurring during 2009, the 
year of the ARRA stimulus package as well as the trough of the Great Recession, had unusually large short-run impacts on GDP.

Papaioannou (2016) uses a structural VAR econometric framework and estimates multipliers of public investment spending based on a compilation of quarterly time series datasets for each EU country during the period 1995-2015. The econometric results confirm that output responses are not uniform across EU countries and vary significantly over time. The magnitude of the output response after a shock in public investment is positive for most of the EU countries, but remains very low or is even negative for a few. Upon constructing measures of public sector efficiency for EU-28 countries in the period 2004-2014, this author finds that the efficiency of public sector matters a great deal in raising the influence of public investment on growth, concluding that governments should focus more on the proper allocation of their resources as a means to maximize the growth influence of public investment.

Focusing on a specific EU country i.e. Portugal, Pereira and Pereira (2017) employ a VAR model to estimate the long-term elasticities and marginal products of output, employment, and private investment with respect to infrastructure investment through an analysis of the resulting impulse-response functions. In particular, the model decomposes the marginal products between the short-term/demand effects on impact and the long-term/supply side effects, mapping the evolution of the marginal products over time in order to identify patterns of decreasing marginal returns. The authors consider the effects of one-percentage point, one-time shock in the rates of growth of the different types of infrastructure investment. The decomposition of the marginal product shows that for some infrastructure (national roads, ports, airports and education infrastructures) the short-term effects are higher than long term effects; while for other infrastructure projects such as railroads, health, and telecommunications, the impact has mostly a long term and supply side nature. Finally, investments in health and airports exhibit decreasing marginal returns, while returns of railroads, ports, and telecommunications are relatively constant with respect to scale. Cristian et al. (2010) analyzed Romania's GDP reaction to the change of the state's gross fixed capital formation by means of an OLS regression. The results obtained are in accordance with OECD (2009) estimates for the emerging countries from the Eastern and Central Europe. Public projects do not appear to have an immediate impact upon the rate of economic growth, because of various kinds of implementation delays. The elasticity of GDP to annual percentage change of the state's gross fixed capital formation is 0.016 , namely an increase equal to $1 \%$ of public investments determines an additional economic growth of GDP of $0.016 \%$ within approximately nine months. The multiplier of the public investments is 0.7 , i.e. an increase of investments by 1 euro determines an increase of GDP by only 0.7 euro after three quarters.

According to a DSGE study by OECD (2009), most advanced countries exhibit short run public investment multipliers lower than 1 (0.7 in Belgium, Neth- 
erlands, Ireland Czech Republic, Hungary, Slovakia and Poland; 0.8 in Germany, France, Italy and Great Britain; 0.9 in the USA) and medium term multipliers approximately equal to 1 (in Germany, France, Italy, Spain and Great Britain). Other DSGE models focus on the role of monetary policy, and especially the cases where interest rate is close to the zero lower bound (ZLB). In this regard, Eggertsson (2011) importantly notes that for government spending to be effective at increasing demand at the ZLB, it has to be directed at goods that are imperfect substitutes with private consumption, such as infrastructure or military spending.

Within the DSGE models, a recent study (2014) applies the IMF's Globally Integrated Monetary and Fiscal model to investigate the effect of public investment on growth in advanced and emerging economies. For the developed economies, performing simulations with a DSGE model under interest rates close to zero for two years, the results of this study suggest that a 1\% of GDP increase in public investment increases output by about $2 \%$ in the same year. Output declines in the third year after the shock, as monetary policy normalizes, then increases to $2.5 \%$ over the long term because of the resulting higher stock of public capital. The large output effects imply that the debt-to-GDP ratio declines, by about 3 percentage points of GDP three years after the shock, after which it increases somewhat, stabilizing at about 1.5 percentage points of GDP below the baseline five years after the shock. The study finds much smaller effects under normal conditions of less slack and an immediate monetary policy response to the increase in public investment, in which case the debt-to-GDP ratio would eventually rise, stabilizing at a level 1.5 percentage points of GDP higher than the baseline. For emerging economies the results of the IMF study suggest that a $1 \%$ of GDP increase in public investment increases output less than $1 \%$ in the same year. Output remains more or less stable in the six year after the shock, then it increases to $1.3 \%$ over the long term. The output effects imply that the debt-to-GDP ratio increases, by about 4 percentage points of GDP in the five years after the shock, after which it is stabilized. According to IMF results, then, the response of output to public investment shocks is smaller in emerging market economies and it could depend on the low level of efficiency in the investment process. Moreover model-based simulations suggest that public investment, even if it raises output in both the short and long term, determines a permanent increase of public debt-to-GDP ratios. However this negative fiscal consequence should be more than compensated by social gains due to an increase of public investment mainly in infrastructure, whose insufficient level may be an important constraint to growth. In other words the gains due to a higher level of infrastructures could be large.

As we have already noted, the global financial crisis and the consequent euro area sovereign debt crisis has induced the governments of many advanced economies to increase tax revenues and to implement expenditure cuts especially for investments/infrastructures. For this reason, recent econometric studies have 
been focusing on fiscal multipliers associated with consolidation (i.e. policies undertaken by governments to reduce their deficits and accumulation of debt stock). In this context some economists have argued that the fiscal consolidation should allow some support to growth through public investment (Spilimbergo et al., 2009; Romer, 2012; Hakhu et al., 2014).

According to Hakhu et al. (2014), there is a negative relationship between public investment spending and debt financing in the EU area, so that strengthening the sustainability of EU public finances can be obtained by rising public investment in technology and infrastructures. For the Euro area, Jovanovic (2014) develops an empirical model that compares government investment and consumption multipliers across 37 developed economies during 2011 and 2012. He finds that investment multipliers are generally higher than 1 and in the highly-indebted countries seem to be substantially higher, by more than 1 (1.7), than those that were assumed in the forecast. The author concludes that during the consolidation period (2011-2012): 1) the investment multiplier is higher for the indebted countries ${ }^{7}$; 2 ) in the same countries the investment multiplier is likely to be higher than the consumption multiplier and, 3) consolidation should be accompanied by increased public investment, especially in countries that have a high public debt. Empirical work from the IMF (2010) estimates effects of fiscal consolidation using an autoregressive equation of a growth rates with annual data (1980-2009) and for 15 advanced economies, finding significant evidence that fiscal consolidation is typically contractionary. Recently Masten and Grdovic Gnip (2019) focusing on South-east Europe countries, find evidence that public investment plays an important role in boosting economic activity and should thus be advocated or prioritized over fiscal consolidation.

Fournier (2016) focuses on long-term effects of public investment projects, by estimating their average impact and providing some insights on the specific factors that contribute to their effectiveness in practice. The most important findings from his analysis can be summarized as follows: 1) increasing the share of public investment in total government spending yields large growth gains; 2) these effects are highest in sectors that are associated with large externalities, such as research and development or health, and they are lowest in countries where the public capital stock is already high (e.g. Japan); 3) a spending shift towards public investment, away from other spending, would also speed up the convergence of lagging countries towards the income of the most advanced economies; 4) in terms of economic policies, governments should implement sound public investment policies (provide the right incentives, carry out cost/benefit analysis underpinned with good data) and focus on sectors with high externalities, because public investment is a key instrument to achieve long ${ }^{7}$ This result is surprising because the recent literature supports the hypothesis that high public debt reduces the multiplier, by increasing the likelihood of a default in the future (see Auerbach \& Gorodnichenko, 2012a; Ilzetzki et al., 2013; Kirchner et al., 2010; Nickel \& Tudyka, 2013 and Rusnak, 2011). 
run growth.

\section{Main Conclusion on the Empirical Studies}

This survey has focused on the impact of public investment as an instrument of economic policy, taking into account its short and long run effects on various aspects of the economy. In addition to a review of the theoretical principles and main models to evaluate the investment impact, we have also presented and analyzed features and results of the most empirical work on this theme (see Table 1 for a summary of the main studies), taking into account of both theory and estimations issues. In particular, the empirical studies surveyed have been analyzed from the point of view of the underlying theory, their research approach and the results obtained.

From a methodological point of view, empirical studies follow two main approaches: 1) aggregate simulation modeling and 2) econometrics. The aggregate modeling approach mainly relies on the so called dynamic stochastic general equilibrium models (DSGEs) which in turn are of two main varieties: New Business Cycle (NBC) and new Keynesian (NK) models. In both cases these models by construction assume that public and private sectors compete for resources and that public expenditure policies have limited effects on the economy and tend to support the idea that fiscal expansion is especially effective when monetary policies have exhausted their power. They also suggest that when the central bank is able to keep interest rates stable and low, fiscal multipliers may be much larger than 1. Moreover, many of these models do show a more effective action on income and growth of public investment as compared to current expenditure, in part as a form of hysteresis that tends to cumulate even small increments or decrements of productivity over time.

Empirical studies based on econometric analysis are somewhat at odds with the DSGE indications. They support the idea that public investment, if projects are properly selected, raises output through both demand and supply effects. However, they also find more ambiguous short-run effects. These should be further investigated before a convincing answer on their overall impact can be provided since many econometric results suggest that their positive impact on output and growth is positive only for some types of infrastructure investment. In general, a vast body of empirical literature seems to agree on the fact that public investment is more likely to have positive effects on the economy than current expenditure both in the short and in the long run.

These positive conclusions are subjected to criticism because the empirical models employed are not able to consider all theoretical aspects related to on how additional public capital can affect economic growth. The heart of the problem is the difficulty in identifying truly exogenous and unanticipated changes in public investment in the macroeconomics data and also in tracking their dynamic effects over time. VAR models appear better suited to address the issue of the effective impact and are easier to estimate than structural models 
Table 1. Empirical studies on short and long run effects of public investment

\begin{tabular}{|c|c|c|c|}
\hline \multirow{2}{*}{$\begin{array}{l}\text { Models/Approach/ } \\
\text { Analysis }\end{array}$} & \multirow{2}{*}{ Authors } & \multirow{2}{*}{$\begin{array}{l}\text { Countries/ } \\
\text { case studies }\end{array}$} & Main Results \\
\hline & & & Short Term \\
\hline \multirow[t]{2}{*}{$\begin{array}{l}\text { Meta-regression } \\
\text { studies }\end{array}$} & $\begin{array}{l}\text { Spilimbergo } \\
\text { et al. (2009) } \\
\text { (based on IMF } \\
\text { staff note 2009) }\end{array}$ & $\begin{array}{l}\text { Advanced } \\
\text { countries }\end{array}$ & $\begin{array}{l}\text { Multiplier on capital spending depends on the } \\
\text { size and openness of the surveyed country. It } \\
\text { ranges between } 0.5 \text { to } 1.8\end{array}$ \\
\hline & Gechert (2015) & $\begin{array}{l}104 \text { studies } \\
(1992-2012)\end{array}$ & $\begin{array}{l}\text { Effects on GDP growth of investment } \\
\text { multiplier is higher than the consumption } \\
\text { multiplier }\end{array}$ \\
\hline $\begin{array}{l}\text { MACRO models } \\
\text { (NiGEM, FF, FM, } \\
\text { OECD interlink, } \\
\text { NAWM, GIMF and } \\
\text { EAGLE) }\end{array}$ & $\begin{array}{l}\text { Mourougane } \\
\text { et al. (2016) }\end{array}$ & $\begin{array}{l}\text { OECD } \\
\text { countries }\end{array}$ & $\begin{array}{l}\text { An increase in the public investment of } 0.5 \% \\
\text { of GDP (temporary deficit-financed in the } \\
\text { short term; fixed interest rates) raise output } \\
\text { by } 0.4 \%-0.6 \% \text { in the first year on average in } \\
\text { the large advanced countries }\end{array}$ \\
\hline
\end{tabular}

\section{Long Term}

IMF (2014)
Advanced and For advanced economies: a 1\% of GDP emerging market economies (2013-2023)

\begin{tabular}{|c|c|c|c|}
\hline & & $\begin{array}{l}\text { emerging } \\
\text { market } \\
\text { economies } \\
(2013-2023)\end{array}$ & $\begin{array}{l}\text { increase in public investment increases output } \\
\text { by about } 2 \% \text { in the same year } \\
\text { For emerging market: a } 1 \% \text { of GDP increase } \\
\text { in public investment increases output less } \\
\text { than } 1 \% \text { in the same year }\end{array}$ \\
\hline \multirow{5}{*}{$\begin{array}{l}\text { VAR and other } \\
\text { empirical analysis } \\
\text { models }\end{array}$} & ECB (2016) & $\begin{array}{l}\text { Large euro } \\
\text { area country } \\
\text { (Germany) } \\
\text { Rest of Euro } \\
\text { area }\end{array}$ & $\begin{array}{l}\text { An increase of public investment equal to } 1 \% \\
\text { of the initial GDP over } 20 \text { quarters } \\
\text { (debt-financed) determines a positive impact } \\
\text { equal to } 1.5 \text { on GDP for Germany and around } \\
\text { to } 0.5 \text { on GDP for Rest of Euro Area (year } 1 \text { - } \\
2 \text { average) }\end{array}$ \\
\hline & $\begin{array}{l}\text { Auerbach and } \\
\text { Gorodnichemko } \\
(2012 a)\end{array}$ & $\begin{array}{l}\text { United States } \\
(1947-2008)\end{array}$ & $\begin{array}{l}\text { An } 1 \$ \text { increase in investment spending } \\
\text { determines a cumulative investment } \\
\text { multiplier equal to: 1) } 2.39 \text { (linear model); } 2 \text { ) } \\
3.42 \text { in recession; } 3 \text { ) } 2.27 \text { in expansion }\end{array}$ \\
\hline & $\begin{array}{l}\text { Blanchard and } \\
\text { Perotti (2002) }\end{array}$ & $\begin{array}{l}\text { United States } \\
(1960-1997)\end{array}$ & $\begin{array}{l}\text { Increase government spending: } 0.9 \text { (first } \\
\text { quarter -maximum value) and } 0.55 \text { (after one } \\
\text { year) }\end{array}$ \\
\hline & Ramey (2011) & $\begin{array}{l}\text { United States } \\
(1939-2008)\end{array}$ & $\begin{array}{l}\text { Increase government spending in response to } \\
\text { military events: } 1.1-1.2 \text { on GDP (first year) }\end{array}$ \\
\hline & $\begin{array}{l}\text { Leduc and } \\
\text { Wilson (2013) }\end{array}$ & $\begin{array}{l}\text { United States- } \\
\text { state level } \\
(1990-2010)\end{array}$ & $\begin{array}{l}\text { Highway spending shocks positively affect } \\
\text { GDP: multipliers range between } 1 \text { and } 3 \text { on } \\
\text { impact }\end{array}$ \\
\hline
\end{tabular}

Permanent increase in public investment of $0.5 \%$ of GDP: 1 ) increases long-term output by about $2 \%$ (FM model) 2) raise output in the long term by $1.8 \%$ on average in OECD countries and $1.6 \%$ in the large advanced economies (F\&F model) 3 ) long-term impact on output, around $0.5 \%$ on average in the large advanced economies (NiGEM model)

For advanced economies: a $1 \%$ of GDP increase in public investment determines an output declines in the third year after the shock (as monetary policy normalizes) then it increases to $2.5 \%$ over the long term because of the resulting higher stock of public capital For emerging market: with a $1 \%$ of GDP increase in public investment output remains more or less stable in the six year after the shock, then it increases to $1.3 \%$ over the long term. The debt-to-GDP ratio increases, by about 4 percentage points of GDP in the five years after the shock, after which it is stabilized

An increase of public investment equal to $1 \%$ of the initial GDP over 20 quarters (debt-financed) determines a positive impact equal to 1.7 on GDP for Germany and less than 0.1 on GDP for Rest of Euro Area (after 10 years)

Increase government spending: 0.66 (after five years) five years)

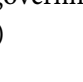

Highway spending shocks positively affect GDP: multipliers range between 3 and 7 at six to eight years after the shocks 


\section{Continued}

$\begin{array}{ll}\text { Jovanovic } & 78 \text { countries } \\ \text { (2014) } & (2011-2012 ; \\ & \text { consolidation } \\ & \text { period) }\end{array}$

Papaioannou For each EU

(2016) country

(Quarterly

time series

datasets

1995-2015)

Ilzetzki et al. High income

(2013) countries

(1960-2007)

Pereira and Portugal

Pereira (2017) （1978-2012)

Fournier (2016) OECD

countries

(2009-2013)
The responses of output after a public investment shock are not uniform across EU countries and vary significantly. It range from -2.72 (Lithuania) to 2.08 (Germany)

Positive "pure" public investment shock. Multiplier on impact 0.4

Effects of one-percentage point, one-time shocks in the rates of growth of the different types of infrastructure investment (marginal products): National roads 6.72; Municipal Roads-1.81; Highways 1; Railroads 2.62; Ports 4.66; Airports 18.43; Health 3.91; Educational 6.01; Water 2.11; Petroleum 0.39; Electricity and Gas 0.35 ; Telecommunications 4.44

Positive effects of public investment on potential growth rate of GDP per capita. Coefficient is equal to 0.098

RBC models

Baxter and King United States

Mazraani (2010) United States

Production Aschauer (1989) United States Function Approach (1983) (1955-2008)

Aschauer (1989) United State
(1949-1985)

Multiplier of permanent increase in government purchases: $>1$ on GDP

A $1 \%$ increase in government investment: increase private investment by $0.04 \%$ and output by $0.0085 \%$
The investment multipliers in the highly-indebted countries are more than one (1.7). Investment multiplier is likely to be higher in countries with high public debt than in countries with not-so-high public debt

Positive "pure" public investment shock. Cumulative spending multiplier 1.5 after 5 years

Effects of one-percentage point, one-time shocks in the rates of growth of the different types of infrastructure investment (marginal products): National roads 5.70; Municipal Roads 1.02; Highways 3.55;

Railroads 11.36; Ports 9.75; Airports 26.52; Health 16.54; Educational 10.04; Water 4.80; Petroleum 3.05; Electricity and Gas 0.40; Telecommunications 10.70

Effects of public investment on potential growth rate of GDP per capita: Increasing the share of public investment in primary spending by $1 \%$ (offset by a reduction in other spending) would increase the long-term GDP level by about 5\% Public investment is a lever to boost growth in the long run

Multiplier of permanent increase in government purchases: $>1$ on GDP

Output elasticity with respect to public capital of 0.0085

The production function includes public capital. It is found a strong positive effects of the public capital stock, and in particular of core infrastructure. The estimated elasticity for the core infrastructure is equals to 0.24 . A $1 \%$ increase in the ratio of public to private capital stocks raises total factor productivity by $0.39 \%$. Crowding-in effect dominates the crowding-out effect

A $1 \%$ of GDP increase in government investment is over to 1.4 (after 40 quarter)

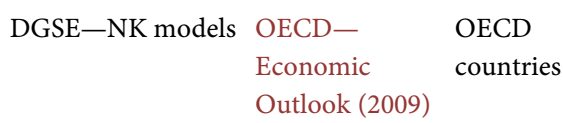

A $1 \%$ of GDP increase in government investment is near to 0.8 (first quarter)

Source: our elaboration. 
especially for capturing non-linear behavior, but this advantage comes at the cost of possibly omitting important structural relationships characterizing the economy.

\section{Policy Implications}

In spite of a great diversity in the theoretical approaches and the empirical results, the studies summarized offer several elements of convergence that can be useful to policy makers. First, if public investments are selected on the basis of valid evaluation methods, they are likely to contribute to increasing production because of their positive effects on both the demand and the supply side. Second, especially the empirical studies suggest that public investment spending has greater effects on economic growth than public consumption spending. Third, while there are empirical difficulties in the exact quantification of its impact, public investment appears to have positive effects on long-term growth and productivity. This effect is also likely to be amplified by its complementary role in favoring private investments and improving their performance ("crowding in" effects). On the other hand, when public capital is low or less productive because of non-performing investment in the past, potential gains from new public projects may be especially large. Fourth, even though the size of the effects are the most contentious matters, there is general agreement that income multipliers can be expected to be larger during recessions and especially large once monetary policies have reached their limit of zero interest rates. Moreover, letting the economy slide below minimal thresholds increases the risk that economic downturns inflict permanent damages to the economy, in the form of structural losses of private and public capital stocks.

These stylized facts suggest that policy makers should exercise greater efforts to plan and implement public investment, and that these efforts should become the main instruments of economic policy both to stabilize the economies during their cyclical gyrations and to optimize their long term growth. Public investment indeed seems to offer an instrument that can be used to counter negative shocks and, at the same time can be used to pursue long term policy goals. This dual role, however, has been neglected and public capital has been eroding in most of the world for several reasons. These include, inter alia, the long lags and practical difficulties involved in planning and implementing public projects and monitoring their performance.

The next step in an economic policy focused on capital expenditure consists in identifying priorities within a broad portfolio of public investments. In this regard, the concept of sustainable development appears increasingly relevant as a criterion of project selection and evaluation of multi-dimensional nature. The concept is also characterized by dynamism because it changes with the economic, social and cultural systems to which it refers and which can be defined as complex (Bertalanffy, 1969).

The question of sustainable development brings to the fore the broader ques- 
tion of global public goods. Ultimately, these goods require public investment, where this can help building institutions and international capabilities of many sorts or, more specifically, global social, human and physical infrastructure. The lack of global public institutions, therefore, goes hand in hand with the inadequacy of the global infrastructure available beyond the main networks that connect the world on the basis of the present web of market and non-market relations. Global infrastructures include the facilities operated by multilateral institutions, which are at present limited to a few research and development laboratories. All institutions that operate at global level are also a form of global public goods, even though they are often operated by private companies with no direction or control on the part of public entities.

As the coronavirus crisis suggests, in a global and hyper-connected economy, sustainable development requires forms of public capital that transcend the usual needs and go beyond the so called base infrastructure to include a much larger basket of global public goods. In this context, multilateral agreements, not only on a voluntary basis, are a priority and could lead to a revision of the transnational institutional structure existing today (Zamagni, 2019). Global governance is therefore fundamental and necessary for the sustainability challenge that affects both the intellectual and the operational plan, that is, that of the governments and institutions called to intervene with adequate and coordinated programs. This latter point implies adequate capabilities to translate global strategies into concrete actions and define more incisive national and supranational policies on these issues. At this stage, critical issues emerge that need a radical change within and outside the institutions to be resolved, based on the satisfaction of the sustainability principles and therefore also on a new paradigm to define investment programs. In order for investments to have positive net effects, there must be correct planning, regulation and implementation mechanisms. According to the IMF (2015) with these assumptions, infrastructure can increase productivity in the long term and be a guide in economic activity in the short term. However, the risk that countries will not be able to seize this opportunity is significant, partly due to multiple failures along infrastructure investment processes ranging from planning to infrastructure deployment. A major risk of pursuing the objective of investing in infrastructure sustainability is also the use of outdated investment development models which were formulated when the sustainability question had not emerged yet (Bhattacharya et al., 2015).

The two main lines of action on a global scale (Agenda 2030 and Cop 21) indicate the way forward to face the challenge of sustainability but alone are not enough, because a huge mobilization of private resources and public development aid is needed to promote further multilateral actions. This is further confirmed by the fact that both strategies recognize the centrality of sustainable infrastructures as a driving force for the transition to sustainable systems, also in light of the positive effects that capital expenditure has on the economy. The global nature and the depth of the present crisis thus suggests the need but also 
the opportunity for policy makers to launch a vast program of global public investment, capable to re-start economic growth according to the principles of economic, social and environmental sustainability.

\section{Funding}

Not applicable.

\section{Availability of Data and Material (Data Transparency)}

Not applicable.

\section{Code Availability}

Not applicable.

\section{Conflicts of Interest}

The authors declare no conflicts of interest regarding the publication of this paper.

\section{References}

Al-Eyd, A., \& Barrell, R. (2005). Estimating Tax and Benefit Multipliers in Europe. Economic Modelling, 22, 759-776. https://doi.org/10.1016/j.econmod.2005.05.005

Ardagna, S. (2001). Fiscal Policy Composition, Public Debt, and Economic Activity. Public Choice, 109, 301-325. https://doi.org/10.1023/A:1013021004195

Aschauer, D. A. (1989). Is Public Expenditure Productive? Journal of Monetary Economics, 23, 177-200. https://doi.org/10.1016/0304-3932(89)90047-0

Auerbach, A., \& Gorodnichenko, Y. (2012a). Measuring the Output Responses to Fiscal Policy. American Economic Journal: Economic Policy, 4, 1-27. https://doi.org/10.1257/pol.4.2.1

Auerbach, A., \& Gorodnichenko, Y. (2012b). Fiscal Multipliers in Recession and Expansion. NBER Working Paper 17447, Cambridge, MA: National Bureau of Economic Research. https://doi.org/10.3386/w17447

Auerbach, A., \& Gorodnichenko, Y. (2013). Structural Reforms and the Potential Effects on the Italian Economy. Journal of Policy Modeling, 35, 88-109. https://doi.org/10.1016/j.jpolmod.2012.03.002

Azariadis, C. (2018). Riddles and Models: A Review Essay on Michel De Vroey's A History of Macroeconomics from Keynes to Lucas and Beyond. Journal of Economic Literature, 56, 1538-1576. https://doi.org/10.1257/jel.20181439

Barro, R. J., \& Redlick, C. J. (2011). Macroeconomic Effects from Government Purchases and Taxes. Quarterly Journal of Economics, 126, 51-102. https://doi.org/10.1093/qje/qjq002

Baxter, M., \& King, R. G. (1993). Fiscal Policy in General Equilibrium. American Economic Review, 83, 315-334.

Bertalanffy, L. (1969). General System Theory, Foundations, Develpoment, Applications. New York: George Braziler Inc.

Bhattacharya, A., Oppenheim, J., \& Stern, L. N. (2015). Driving Sustainable Development 
through Better Infrastructure: Key Elements of a Transformation Program. Brookings, OR: Global Economy and Development, WP 91.

Binswanger, H. P., Khandker, S. R., \& Rosenzweig, M. R. (1993). How Infrastructure and Financial Institutions Affect Agricultural Output and Investment in India. Journal of Development Economics, 41, 337-366. https://doi.org/10.1016/0304-3878(93)90062-R

Blanchard, O., \& Leigh, D. (2013). Growth Forecast Errors and Fiscal Multipliers. American Economic Review, 103, 117-120. https://doi.org/10.1257/aer.103.3.117

Blanchard, O., \& Perotti, R. (2002). An Empirical Characterization of the Dynamic Effects of Changes in Government Spending and Taxes on Output. Quarterly Journal of Economics 117, 1329-1368. https://doi.org/10.1162/003355302320935043

Brock, W., \& Mirman, L. (1972). Optimal Economic Growth and Uncertainty: The Discounted Case. Journal of Economic Theory, 4, 479-513. https://doi.org/10.1016/0022-0531(72)90135-4

Caldara, D., \& Kamps, C. (2008). What Are the Effects of Fiscal Policy Shocks? A VAR-Based Comparative Analysis. Working Paper Series 877, European Central Bank.

Carroll, C. (2009). Comments and Discussion on "By How Much Does GDP Rise If the Government Buys More Output?”. Brookings Papers on Economic Activity, 2, 232-249. https://doi.org/10.1353/eca.0.0069

Chakraborty, S., \& Dabla-Norris, E. (2009). Strategy, Policy, and Review Department the Quality of Public Investment. IMF Working Paper 154.

https://doi.org/10.5089/9781451873016.001

Chandra, A., \& Thompson, E. (2000). Does Public Infrastructure Affect Economic Activity? Evidence from the Rural Interstate Highway System. Regional Science and Urban Economics, 30, 457-490. https://doi.org/10.1016/S0166-0462(00)00040-5

Chichilnisky, G. (2012). Economic Theory and the Global Environment. Economic Theory, 49, 217-225. https://doi.org/10.1007/s00199-011-0630-x

Clausen, B., Kraay, A., \& Nyiri, Z. (2011). Corruption and Confidence in Public Institutions: Evidence from a Global Survey. The World Bank Economic Review, 25, 212-249. https://doi.org/10.1093/wber/lhr018

Cohen, J. P., \& Morrison Paul, C. J. (2003). Airport Infrastructure Spillovers in a Network System. Journal of Urban Economics, 54, 459-473. https://doi.org/10.1016/j.jue.2003.06.002

Corsetti, G., Meier, A., \& Müller, G. J. (2012). What Determines Government Spending Multipliers? Economic Policy, 72, 521-558. https://doi.org/10.1111/j.1468-0327.2012.00295.x

Cristian, S., Aura-Gabriela, S., Marius-Corneliu, M., \& Dorin, M. (2010). The Estimation of the Public Investment Multiplier in Romania. In International Conference on Business and Economics Research (pp. 20-24). Kuala Lumpur: IACSIT Press.

Cwik, T., \& Wieland, V. (2011). Keynesian Government Spending Multipliers and Spillovers in the Euro Area. Economic Policy, 26, 493-549. https://doi.org/10.1111/j.1468-0327.2011.00268.x

de Frutos, R. F., \& Pereira, A. M. (1993). Public Capital and Aggregate Growth in the United States: Is Public Capital Productive? Documentos de Trabajo del ICAE 9313, Universidad Complutense de Madrid, Facultad de Ciencias Económicas y Empresariales, Instituto Complutense de Análisis Económico.

de Haan, J., Romp, W., \& Sturm, J. E. (2008) Public Capital and Economic Growth: Key Issues for Europe. In G. Schwartz, A. Corbacho, \& K. Funke (Eds.), Public Investment 
and Public-Private Partnerships. Procyclicality of Financial Systems in Asia. London: Palgrave Macmillan. https://doi.org/10.1057/9780230593992_2

Delong, J. B., \& Summers, L. H. (2012). Fiscal Policy in a Depressed Economy. Brookings Papers on Economic Activity, 44, 233-297. https://doi.org/10.1353/eca.2012.0000

Edelberg, W., Eichenbaum, M., \& Fisher, J. D. M. (1999). Understanding the Effects of a Shock to Government Purchases. Review of Economic Dynamics, 2, 166-206. https://doi.org/10.1006/redy.1998.0036

Egger, H., \& Falkinger, J. (2003). The Role of Public Infrastructure for Firm Location and International Outsourcing. CESIfo Working Paper 970.

Eggertsson, G. B. (2011). What Fiscal Policy Is Effective at Zero Interest Rates? NBER Macroeconomics Annual, 25, 59-112. https://doi.org/10.1086/657529

Eggertsson, G. B., \& Krugman, P. (2012). Debt, Deleveraging, and the Liquidity Trap: A Fisher-Minsky-Koo Approach. Quarterly Journal of Economics, 127, 1469-1513. https://doi.org/10.1093/qje/qjs023

European Central Bank ECB (2016). Public Investment in Europe. Economic Bulletin, Issue 2.

Fatàs, A., \& Mihov, I. (2001). The Effects of Fiscal Policy on Consumption and Employment: Theory and Evidence. Discussion Papers 2760, London: CEPR.

Fisher, J. D. M., \& Peters, R. (2010). Using Stock Returns to Identify Government Spending Shocks. Economic Journal, 120, 414-436. https://doi.org/10.1111/j.1468-0297.2010.02355.x

Fournier, J. (2016). The Positive Effect of Public Investment on Potential Growth. Working Papers 1347, Paris: OECD Economics Department, OECD Publishing.

Freedman, C., Kumhof, M., Laxton, D., Muir, D., \& Mursula, S. (2010). Global Effects of Fiscal Stimulus during the Crisis. Journal of Monetary Economics, 57, 506-526. https://doi.org/10.1016/j.jmoneco.2010.05.003

Fujita, M., Krugman, P. R., \& Venables, A. J. (1999). The Spatial Economy. Cambridge, MA: MIT Press.

Galì, J., Lopez-Salido, J. D., \& Valles, J. (2007). Understanding the Effects of Government Spending on Consumption. Journal of the European Economic Association, 5, 227-270. https://doi.org/10.1162/JEEA.2007.5.1.227

Gechert, S. (2015). What Fiscal Policy Is Most Effective? A Meta-Regression Analysis. Oxford Economic Papers, 67, 553-580. https://doi.org/10.1093/oep/gpv027

Gechert, S. (2017). On Theories and Estimation Techniques of Fiscal Multipliers. Macro-Economic Policy Institute (IMK), FMM-Working Paper 11.

Gertler, P. J., Martinez, S., Premand, P., Rawlings, L. B., \& Vermeersch, C. M. J. (2016). Impact Evaluation in Practice (2nd ed.). Washington DC: Inter-American Development Bank and World Bank. https://doi.org/10.1596/978-1-4648-0779-4

https://openknowledge.worldbank.org/handle/10986/25030

Hakhu, A. B., Piergallini, A., \& Scaramazzino, P. (2014). Public Capital Expenditure and Debt Dynamics: Evidence from the European Union. London: Centre for Financial \& Management Studies, SOAS, University of London.

Haughwout, A. F. (2002). Public Infrastructure Investments, Productivity and Welfare in Fixed Geographic Areas. Journal of Public Economics, 83, 405-428. https://doi.org/10.1016/S0047-2727(00)00164-X

Hausman, J. K. (2016). Fiscal Policy and Economic Recovery: The Case of the 1936 Veterans' Bonus. American Economic Review, 106, 1100-1143. 
https://doi.org/10.1257/aer.20130957

Hirschman, A. O. (1958). The Strategy of Economic Development. New York: Yale University Press.

Holtz-Eakin, D., \& Lovely, M. E. (1996). Scale Economics, Returns to Variety, and the Productivity of Public Infrastructure. Regional Science and Urban Economics, 26, 105-123. https://doi.org/10.1016/0166-0462(95)02126-4

Ilzetzki, E., Mendoza, E. G., \& Vegh, C. A. (2013). How Big (Small?). Are Fiscal Multipliers? Journal of Monetary Economics, 60, 239-254.

https://doi.org/10.1016/j.jmoneco.2012.10.011

International Monetary Fund IMF (2010). World Economic Outlook, Ch. 3 Will It Hurt? Macroeconomic Effects of Fiscal Consolidation.

International Monetary Fund IMF (2012). Fiscal Monitor. Washington DC: International Monetary Fund.

International Monetary Fund IMF (2014). Is It Time for an Infrastructure Push? The Macroeconomic Effects of Public Investment. In World Economic Outlook, Legacies, Clouds, in Certainties (Ch. 3, pp. 75-114). Washington DC.

International Monetary Fund IMF (2015). Making Public Investment More Efficient. Washington DC: International Monetary Fund.

https://doi.org/10.5089/9781498344630.007

Jones, C. I. (2008). Intermediate Goods, Weak Links, and Superstars: A Theory of Economic Development. NBER Working Papers Series 13834. https://doi.org/10.3386/w13834

Jovanovic, B. (2014). Growth Forecast Errors and Government Investment and Consumption Multipliers. Tor Vergata University, CEIS Research Paper 301.

https://doi.org/10.2139/ssrn.2368859

Kehoe, T. J., \& Prescott, E. C. (1995). Introduction to the Symposium: The Discipline of Applied General Equilibrium. Economic Theory, 6, 1-11.

https://doi.org/10.1007/BF01213938

Keynes, J. M. (1936). The General Theory of Employment, Interest and Money. London: Macmillan.

Kirchner, M., Cimadomo, J., \& Hauptmeier, S. (2010). Transmission of Government Spending Shocks in the Euro Area: Time Variation and Driving Forces. Working Paper Series 1219, Frankfurt: European Central Bank. https://doi.org/10.2139/ssrn.1551801

Krugman, P. R. (1991). Increasing Returns and Economic Geography. Journal of Political Economy, 99, 483-499. https://doi.org/10.1086/261763

Kydland, F. E., \& Prescott, E. C. (1982). Time to Build and Aggregate Fluctuations. Econometrica, 50, 1345-1370. https://doi.org/10.2307/1913386

Leduc, S., \& Wilson, D. (2013). Roads to Prosperity or Bridges to Nowhere? Theory and Evidence on the Impact of Public Infrastructure Investment. In NBER Macroeconomics Annual 2012 (Ch. 2). Cambridge, MA: National Bureau of Economic Research. https://doi.org/10.3386/w18042

Leontief, W. W. (1936). Quantitative Input and Output Relations in the Economic Systems of the United States. The Review of Economics and Statistics, 18, 105-125. https://doi.org/10.2307/1927837

Linnemann, L. (2006). The Effect of Government Spending on Private Consumption: A Puzzle? Journal of Money, Credit, and Banking, 38, 1715-1735.

https://doi.org/10.1353/mcb.2006.0094 
Masten, I., \& Grdovic Gnip, A. (2019). Macroeconomic Effects of Public Investment in South-East Europe. Journal of Policy Modeling, 41, 1179-1194.

https://doi.org/10.1016/j.jpolmod.2019.05.005

Mazraani, S. (2010). Public Expenditures in an RBC Model: A Likelihood Evaluation of Crowding-In and Crowding-Out Effects. Pittsburgh: University of Pittsburgh, Department of Economics Mimeo.

Mountford, A., \& Uhlig, H. (2009). What Are the Effects of Fiscal Policy Shocks? Journal of Applied Econometrics, 24, 960-992. https://doi.org/10.1002/jae.1079

Mourougane, A., Botev, J., Fournier, J. M., Pain, N., \& Rusticelli, E. (2016). Can an Increase in Public Investment Sustainably Lift Economic Growth? Working Papers 1351, OECD Economics Department.

Nakamura, E., \& Steinsson, J. (2014). Fiscal Stimulus in a Monetary Union: Evidence from US Regions. American Economic Review, 104, 753-792. https://doi.org/10.1257/aer.104.3.753

Nickel, C., \& Tudyka, A. (2013). Fiscal Stimulus in Times of High Debt: Reconsidering Multipliers and Twin Deficits. Working Paper Series 1513, Frankfurt: European Central Bank.

OECD (2009). Economic Outlook. Interim Report, March.

OECD (2014). Economic Policy. Reforms: Going for Growth.

Papaioannou, S. (2016). Public Investment Multipliers in EU Countries: Does the Efficiency of Public Sector Matter? Athens: Centre of Planning and Economic Research. https://doi.org/10.2139/ssrn.2755247

Parker, J. A. (2011). On Measuring the Effects of Fiscal Policy in Recessions. Journal of Economic Literature, 49, 703-718. https://doi.org/10.1257/jel.49.3.703

Perali, F., \& Scandizzo, P. L. (2018). The New Generation of Computable General Equilibrium Models. Modeling the Economy. Berlin: Springer International Publishing. https://doi.org/10.1007/978-3-319-58533-8

Pereira, A., \& Pereira, R. (2017). Is All Infrastructure Investment Created Equal? The Case of Portugal. MPRA Paper 77369.

Quesnay, F. (1972). Tableau économique. Creative Media Partners.

Ramey, V. A. (2011). Identyfing Government Spending Shocks: It's All in the Timing. Quarterly Journal of Economics, 126, 1-50. https://doi.org/10.1093/qje/qjq008

Ramey, V. A., \& Shapiro, M. D. (1998).). Costly Capital Reallocation and the Effects of Government Spending. Carnegie-Rochester Conference Series on Public Policy, 48, 145-194. https://doi.org/10.1016/S0167-2231(98)00020-7

Romer, C. (2012). Fiscal Policy in the Crisis: Lessons and Policy Implication. IMF Fiscal Forum.

Romer, C. D., \& Romer, D. H. (2010). The Macroeconomic Effects of Tax Changes: Estimates Based on a New Measure of Fiscal Shocks. American Economic Review, 100, 763-801. https://doi.org/10.1257/aer.100.3.763

Romp, W. E., \& de Haan, J. (2005). Public Capital and Economic Growth: A Critical Survey. EIB Papers, 10, 41-70.

Rusnak, M. (2011). Why Do Government Spending Multipliers Differ? A Meta-Analysis. Mimeo.

Spilimbergo, A., Symansky, S., \& Schindler, M. (2009). Fiscal Multipliers. IMF Staff Position Note 09/11, Washington DC: International Monetary Fund.

https://doi.org/10.5089/9781462372737.004 
Stone, R. (1960). Input-Output and National Accounts. Paris: OECD.

Straub, S. (2008). Infrastructure and Growth in Developing Countries: Recent Advances and Research Challenges. World Bank Policy Research Working Paper 4460, Washington DC: World Bank. https://doi.org/10.1596/1813-9450-4460

Sturm, J. E., Kuper, G. H., \& de Haan, J. (1998). Modelling Government Investment and Economic Growth on a Macro Level: A Review. In S. Brakman, H. van Ees, \& S. K. Kuipers (Eds.), Market Behaviour and Macro-Economic Modelling (pp. 359-406). London: MacMillan Press Ltd. https://doi.org/10.1007/978-1-349-26732-3_14

Summers, L. H. (2013). Remarks in Honor of Stanley Fischer. In Fourteenth Jacques Polak Annual Research Conference. International Monetary Fund, Washington DC, 7-8 November 2013.

Teulings, C., \& Baldwin, R. (2014). Secular Stagnation: Facts, Causes and Cures. London: Centre for Economic Policy, Research.

Venables, A. J. (1996). Equilibrium Locations of Vertically Linked Industries. International Economic Review, 37, 341-359. https://doi.org/10.2307/2527327

Warmedinger, T., Checherita-Westphal, C., \& Hernández de Cos, P. (2015). Fiscal Multipliers and Beyond. Frankfurt: European Central Bank, Occasional Paper Series 162, June.

Warner. A. M. (2014). Public Investment as an Engine of Growth. IMF Working Paper 14 (148). https://doi.org/10.5089/9781498378277.001

Woodford, M. (2011). Simple Analytics of the Government Expenditure Multiplier. American Economic Journal Macroeconomics, 3, 1-35. https://doi.org/10.1257/mac.3.1.1

World Bank (1994). Annual Report.

Zamagni. S. (2019). Ecologia Integrale Come Chiave Di Volta. Fondazione Lombarda per l'Ambiente (a cura di). Sviluppo Umano e Ambiente. Piccola Casa Editrice.

Zanna, L. F., Buffie, E. F., Portillo, R., Berg, A., \& Pattillo, C. (2019). Borrowing for Growth: Big Pushes and Debt Sustainability in Low-Income Countries. The World Bank Economic Review, 33, 661-689. https://doi.org/10.1093/wber/lhy029 